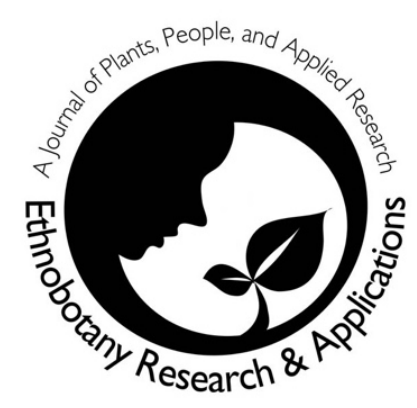

Socio-economic position of Chamaerops humilis L. var. argentea Andre in the province of Taza (North East Morocco) and impact of the new Moroccan law $n^{\circ}$ 77-15 (Moroccan Official Bulletin $\mathrm{N}^{\circ}$ 6422) on the preservation of the environment

Nacima Lachkar, Fatima Lamchouri* and Hamid Toufik

\section{Notes on Ethnobotany}

\begin{abstract}
Background: Chamaerops humilis L. var. argentea Andre is a species that exists in abundance in the province of Taza. It is a valuable source of income for the local population, which improves living conditions and reduces poverty. Hence, the importance of highlighting and quantifying the economic interest of this variety for the local population.
\end{abstract}

Methods: In this regard, for the first time, a survey was conducted in the region to assess the socioeconomic importance of Chamaerops humilis, as well as the impact of the new Moroccan law $n^{\circ} 77-15$ on the ban of the use of plastic bags on its economic position. The study was carried out through a survey using 239 questionnaire sheets in five stations, conducted over two periods before (March- May, 2016) and after (November, 2016- March, 2017) the application of the new law.

Results: Our study finds that Chamaerops humilis has a considerable economic value for the local population. The results showed that Chamaerops humilis is an important source of revenue through the sale of the palm heart (43.22 $€ /$ week/exploiter), and marketing of artisanal products (Doum baskets: 6.2 $€ /$ week/maker). Moreover, the application of the new law had a considerable impact on the basketry market, mainly on the marketing of Doum baskets (14.02 $€ /$ week/maker) to replace plastic bags.

Correspondence
Nacima Lachkar, Fatima Lamchouri*, Hamid
Toufik
Laboratory of Natural Substances, Pharmacology,
Environment, Modeling, Health \& Quality of Life
(SNAMOPEQ), Polydisciplinary Faculty of Taza, Sidi
Mohamed Ben Abdellah University of Fez, B.P.:
1223 Taza-Gare, Taza, Morocco.
'Corresponding Author:
fatima.lamchouri@usmba.ac.ma -
fatima.lamchouri@gmail.com
Ethnobotany Research \& Applications
$\mathbf{2 0 : 3 2 ~ ( 2 0 2 0 )}$


Conclusion: Chamaerops humilis presents a distinguished resource of income for the local population through the jobs it generates. Similarly, the application of Law $n^{\circ} 77-15$ strengthens its economic, social and environmental position, which can contribute to the achievement of local and national sustainable development.

Keywords: Socio-economic Survey; Ecological alternative; Environment; Basketry; Income; Food.

\section{Résumé}

Contexte: Chamaerops humilis L. Var. argentea Andre est une espèce qui existe en abondance dans la province de Taza. Elle représente une source de revenus précieuse pour la population locale, qui permet d'améliorer les conditions d'existence, et réduire la pauvreté. D'où l'importance de mettre en évidence et de quantifier l'intérêt économique de cette variété pour la population locale.

Méthodes: A cet égard, pour la première fois, une enquête a été menée dans la province afin d'évaluer l'importance socio-économique de Chamaerops humilis, ainsi que l'impact de la nouvelle loi marocaine $n^{\circ} 77-15$ sur l'interdiction de l'utilisation des sacs en plastique sur sa position économique. L'étude a été réalisée à travers une enquête à l'aide de 239 questionnaires dans cinq stations, menée sur deux périodes avant (mars - mai 2016) et après (novembre 2016 - mars 2017) l'application de la nouvelle loi.

Résultats: Notre étude montre que Chamaerops humilis a une valeur économique considérable pour la population locale. Les résultats ont montré que Chamaerops humilis est une source importante de revenus grâce à la vente du cœur de palmier $(43,22$ $€ /$ semaine /exploitant), et à la commercialisation de produits artisanaux (paniers Doum : 6,2 $€ /$ semaine / fabricant). Par ailleurs, l'application de la nouvelle loi a eu un impact considérable sur le marché de la vannerie, principalement sur la commercialisation des paniers en Doum (14,02 €/semaine/monteur) pour remplacer les sacs en plastique.

Conclusion: Chamaerops humilis représente une ressource de revenu importante pour la population locale grâce aux emplois qu'elle génère. De même, l'application de la loi $n^{\circ} 77-15$ vient de renforcer la position économique, sociale et environnementale de la plante, ce qui peut contribuer à la réalisation d'un développement durable local et national.

Mots-clés: Enquête socio-économique; Alternative écologique; Environnement; Vannerie; Revenu; Alimentation.

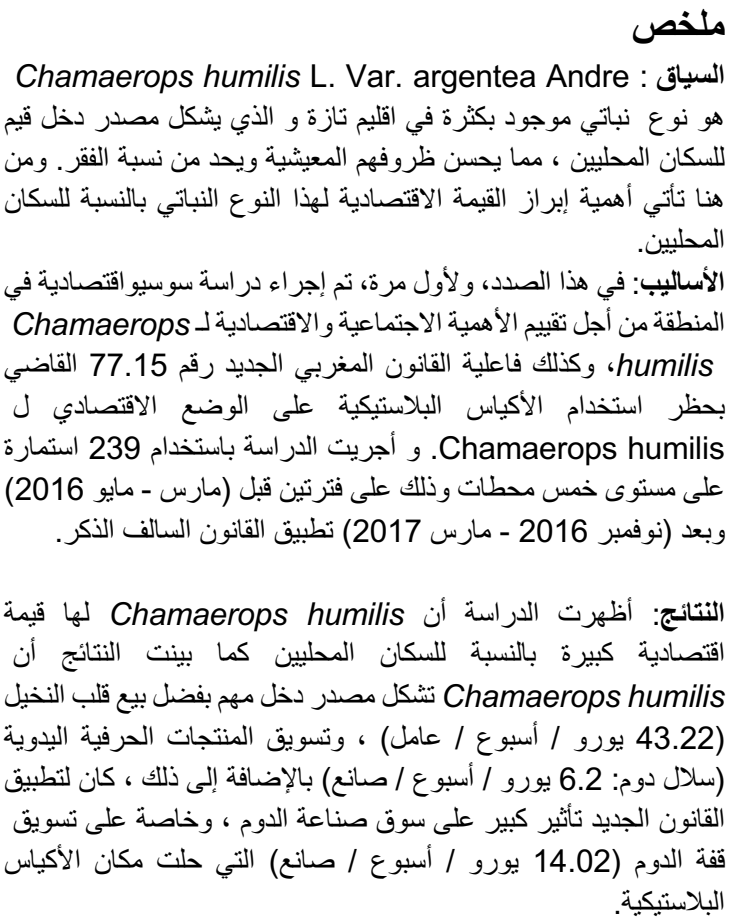

الخلاصة: تمثل Chamaerops humilis مصدر دخل مهم للسكان المحليين بفضل الوظائف التي توفر ها. كما ان تطبيق القانون رقم 77.15

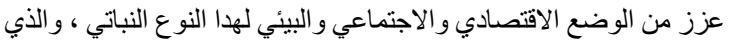
يتوقع أن يساهم في تحقيق التنمية المستدامة المحلية والوطنية.

الكلمات المفاتيح: دراسة سوسيو اقتصادية ، بديل بيئي، قفة الدوم، بيئة،

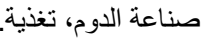

\section{Background}

The use of plastic type materials dates back to antiquity; the Egyptians used glues based on bone gelatin, milk casein, egg albumin, etc. Then, the evolution of plastics processing has been through several stages to meet plastic needs. Not only does plastic raise many environmental issues, but it also harms human health for its containing additives such as phthalates or bisphenol A (Groh et al. 2019, Liu et al. 2019, Piriou \& Bouchaud 2018) which are considered to be endocrine disruptors; these, in turn, can cause toxic complications on the human health such as; endocrine disorders, neurological disorders, cancers, obesity, diabetes, infertility, allergic diseases like asthma and eczema (Groh et al. 2019, Piriou \& Bouchaud 2018, Rochefort 2013). To capitalize on an engagement plan for the fight against global warming, Morocco has implemented a new Moroccan law $\mathrm{n}^{\circ} 77-15$ published in the Moroccan Official Bulletin $\mathrm{N}^{\circ}$ 6422, which entered into force on 1 July, 2016 in order to ban the manufacture, marketing and import of plastic bags. For this purpose, the Moroccan Coalition for Climate Justice (MCCJ) launched a nationwide campaign, under the slogan "Zero Mika", to raise awareness on the dangers of plastic bags and urge Moroccans to 
get rid of them. In addition, to make sustainable development a national priority, Morocco organized the 22nd Conference of the Parties to the United Nations Framework Convention on Climate Change (COP22) from 7 to 18 November, 2016.

Consequently, the application of Moroccan law $n^{\circ} 77$ 15 required the return to traditional herbal basketry items as a new alternative to fill the void left by plastic bags that do not present any environmental risk. These items have long been used in agricultural work as means of transporting products. The Ancient Egyptians had developed many basketry and matting techniques (El Hadidi \& Hamdy 2011). Today, basketry still exists despite the difference in the raw material used: in Europe and mainly in France and Britain, basketry used is that of wicker while North Africans use palm trees for this purpose. In Algeria, dwarf palm leaves are used for very limited handcraft purposes including the manufacture of hats, ballets, baskets (Hasnaoui et al. 2011). In Morocco, however, it is regarded the ideal and most widespread material for rope making. The dwarf palm belongs to the Arecaceae family, and to the genus Chamaerops. It grows on the northern coasts of Africa, from Morocco to Libya, and around the Mediterranean. Only one species, Chamaerops humilis L. exists in the Mediterranean basin. It is one of the two indigenous palm trees in Europe and the only one in the Iberian Peninsula and is a western steno-Mediterranean species (Merlo et al. 1993).

In Morocco, Dwarf Palm trees cover the Great Atlas from the western end of the chain to the Eastern AntiAtlas. This species represents the major physiognomic elements in the region of Taza particularly between Tazzeka and the Piedmont of Boulblane (Quézel et al. 1992).

The plant is remarkable for its socio-economic and environmental interest. Chamaerops humilis L. has long been a product of economic importance in the Maghreb country, mainly in Morocco and Algeria. It is used for the production of vegetable horsehair for industrial use and in automotive industries. Furthermore, this product has replaced animal hair, which is expensive and can be attacked by vermin, causing serious damage and financial loss, while vegetable horsehair made of dwarf palm leaves is less expensive, more profitable and resistant to vermin (Hasnaoui et al. 2011).

In Morocco, the dwarf palm tree is used for several purposes, including artisanal basketry, which is of socio-economic importance. Indeed, since ancient times, Man has manufactured all kinds of objects for daily or agricultural use such as carrying baskets, broomsticks, hats, bags, baskets, fishing twines, etc. Similarly, in the province of Taza, basketry is widely practiced because of the local know-how linked to traditional craftsmanship on the one hand, and the abundance of raw material, leaves of dwarf palm. Based the former Moroccan territorial division, in Taza - Al Hoceima -Taounate region, basketry occupies the second place after textiles. This region has 19.358 craftsperson, of whom 3269 manufacture herbal products, mainly dwarf palm. The marketing of basketry tools represents a source of income to improve the economic situation of the local population, knowing that basketry is the only means of income in some rural areas (Agence Architecture Héritage et Design (Tagemouati et al. 2010). In addition, hearts of palm are sold as a seasonal fruit in the province of Taza. To our knowledge, no study has been carried out on the socio-economic interest of Chamaerops humilis L. var. argentea Andre, neither on the impact of the new Moroccan law $n^{\circ} 77$ 15 published in the Moroccan official bulletin $N^{\circ} 6422$ on the economic position of the species studied. The purpose of this study is therefore to highlight the usefulness of Chamaerops humilis L. var. argentea Andre and its socio-economic significance for the population of the province of Taza, and to shed light on the impact of the new Moroccan law on the economic situation of the species studied.

\section{Material and methods \\ Study area}

The province of Taza is located in the north-east of Morocco (Fig.1), known for its sub-humid climate, and characterized by the diversity and richness of its natural environment. It has one of the biggest and oldest national parks in Morocco, Tazekka Park (Fougrach et al. 2007). According to The Regional Centres of Investment of Fez-Meknes, the provincial area of Taza has an area of $709850 \mathrm{~km}^{2}$ and is inhabited by a predominantly rural of population of 528419. Therefore, agriculture is a major source of economy.

\section{Data collection}

The socio-economic survey was conducted in five stations in the province of Taza: Taza City, Bab El Mrouj, Gualdamane, Bab Boudir, and Bni Frassen, which were chosen for their richness with Chamaerops humilis and because of the ancestral artisanal know-how of the local population diversified into several products including Doum-based basketry. Similarly, we managed to visit three cooperatives in the region of "Bni Frassen" which is located $57 \mathrm{~km}$ away from Taza. The latter has 28014 inhabitants according to the 2004 general population and housing census (Haut-commissariat au Plan 2004). The cooperatives visited were: "Mtiwa Nabat", "El Baraka", and "Znata koufat". 


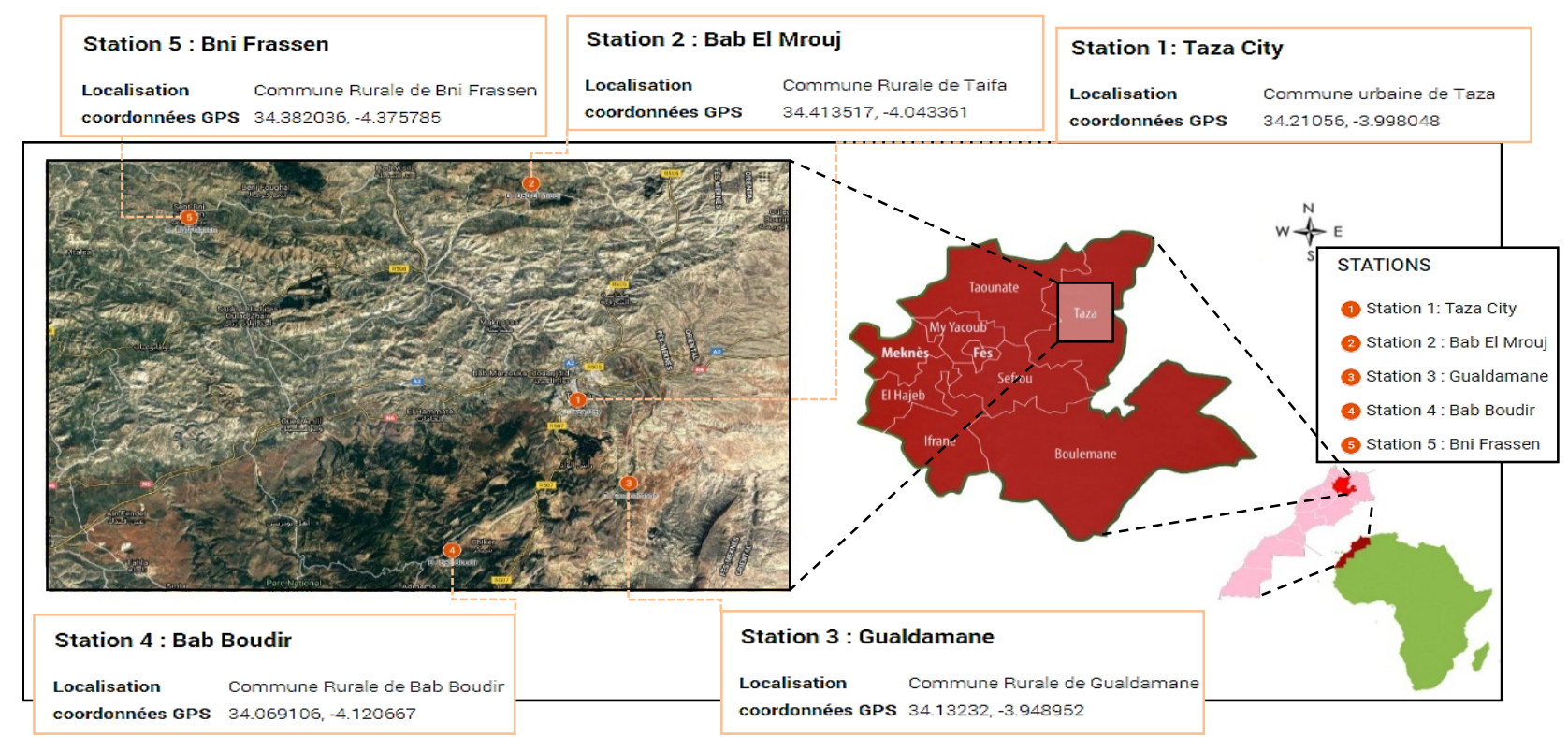

Figure 1. Location of the stations of the socio-economic survey on Chamaerops humilis L. var. argentea Andre in the study area: province of Taza (North-East Morocco)

In addition, to find out about the effect of the application of the new law published in the Moroccan Official Bulletin $\mathrm{N}^{\circ} 6422$ on the prohibition of the manufacture, import, export, marketing and use of plastic bags, we conducted a socio-economic survey over two periods before and after the application of the law N77-15; the first from March to May, 2016 and the second lasted from November 2016 to March 2017.

The method used was that of a questionnaire developed and adopted by the Laboratory of Natural Substances, Pharmacology, Environment, Modeling, Health \& Quality of Life (SNAMOPEQ), Polydisciplinary Faculty of Taza, Sidi Mohamed Ben Abdellah University of Fez, Morocco; it refers to several research studies (Kuniyal et al (2005), Paniagua-Zambrana et al (2007), Mehdioui and Kahouadji (2007), Sher \& Al yemeni (2011), Libiad et al (2011), Khabbach et al (2012), Al-Subaiee (2016), Martins and Shackleton (2018), Martino and Muenzel (2018), Kull et al (2019), Li et al (2019)). The questionnaire is written in French and based on simple and multiple-choice questions, and openended questions on the different uses of Chamaerops humilis L. var. argentea Andre (Ahmad 2018, Eddouks 2017, Sadat-Hosseini et al. 2017, Talukdar et al. 2017).

The population of Taza consists of several tribes including Branès, Ghiata, Tsoul, and the Amazighs, each with its own dialect. There is also a high illiteracy rate. We, consequently, helped the respondents understand the questionnaire using languages spoken in each station (Arabic /amazigh) (Ahmad 2018, Aziz et al. 2017, Heinrich et al. 2018,
Prescott et al. 2017, Weckerle et al. 2018).The documented information was translated into French and English (Talukdar et al. 2017). The population surveyed included farmers, nomads, herbalists, traditional healers and basket makers; we, hence, were able to complete 239 survey forms.

The time spent on each interview was approximately 90 minutes. During each interview, we collected all the information about the targeted respondents and the plant. Profiles of respondents included age, level of education, family situation, profession and ethnicity. The data collected for our plant concerned both artisanal and food use. The socio-economic aspect of our survey was divided into two parts: the first was the sale of the palm heart as a nutrient while the second concerned the sale of basketry products.

\section{Botanical identification}

The botanical identification of the species Chamaerops humilis was carried out by Dr. Abdelmajid Khabbach at the Laboratory of Natural Substances, Pharmacology, Environment, Modeling, Health \& Quality of Life (SNAMOPEQ), Polydisciplinary Faculty of Taza, Sidi Mohamed Ben Abdellah University of Fez, Morocco based on the work of Valdès and the work of Richard (Richard 2005, Valdès et al. 2013).

A reference sample of the plant Chamaerops humilis L. var. argentea Andre is deposited in the herbarium of the Laboratory of Natural Substances, Pharmacology, Environment, Modeling, Health \& Quality of Life (SNAMOPEQ), Polydisciplinary Faculty of Taza, Sidi Mohamed Ben Abdellah University of Fez, Morocco. 


\section{Data analysis}

The data was jotted down on the raw data sheets were then processed and inserted on Excel software. Both quantitative and qualitative statistical methods were for data analysis. Thus, quantitative variables are described using the average, and qualitative variables are described using the numbers and percentages by the following formulas:

$$
\bar{X}=1 / \mathrm{n} \sum_{i=1}^{n} x i(1)
$$

Where $\bar{X}$ indicate the average, $\mathrm{n}$ is the total number of statistical values and $\sum_{i=1}^{n} x i$ is the sum of the values of the statistical series.

$$
\text { Frequency in } \%=\left(\frac{x i}{N}\right) * 100(2)
$$

Where $x i$ the total number of data values, $\mathrm{N}$ is the total number of effective.

\section{Results and Discussion}

The data collected during each interview were transferred to the database, processed and analyzed to obtain standardized data on different aspects of the socio-economic aspect (sale of basketry products, sale of palm hearts) beside the information on the respondents (age, sex, level of education, family situation, profession and ethnicity).

\section{Demographic characteristics of informants Age}

The sample consisted of 239 respondents, with an average age of 50.47 years. Analysis of the data obtained shows that the share of the $30-50,50-70$, $70-90$ age groups represents $48.95 \%, 45.18$ and $5.86 \%$ of the total sample studied (Fig. 2)

\section{Gender}

According to the survey, the study population is composed of $60.75 \%$ men and $39.75 \%$ women (Fig. 3).

\section{The level of study}

Data from the socio-economic survey show that the population studied is characterized by a high illiteracy rate of $65.27 \%$. In addition, of all respondents who were able to attend school, $29.29 \%$ have a primary level, $3.77 \%$ have a secondary level and only $1.67 \%$ have reached the higher education level (Fig. 4).

During this survey, we found that the plant has several uses; artisanal through the manufacture of basketry products with a percentage of $86.61 \%$, and food use for humans and animals with a percentage of 92.88 and $92.46 \%$ respectively.

\section{The percentage of age groups in the study population}

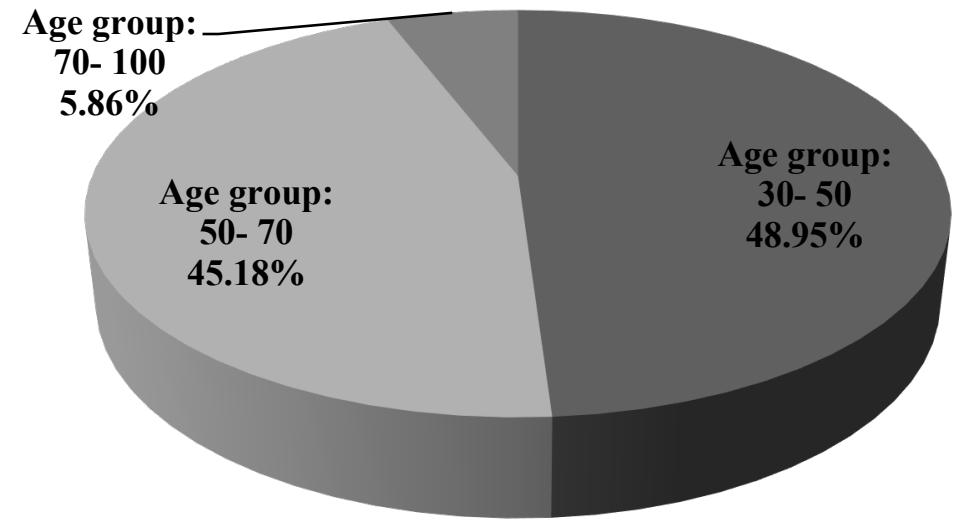

Figure 2. Distribution of respondents by age group 


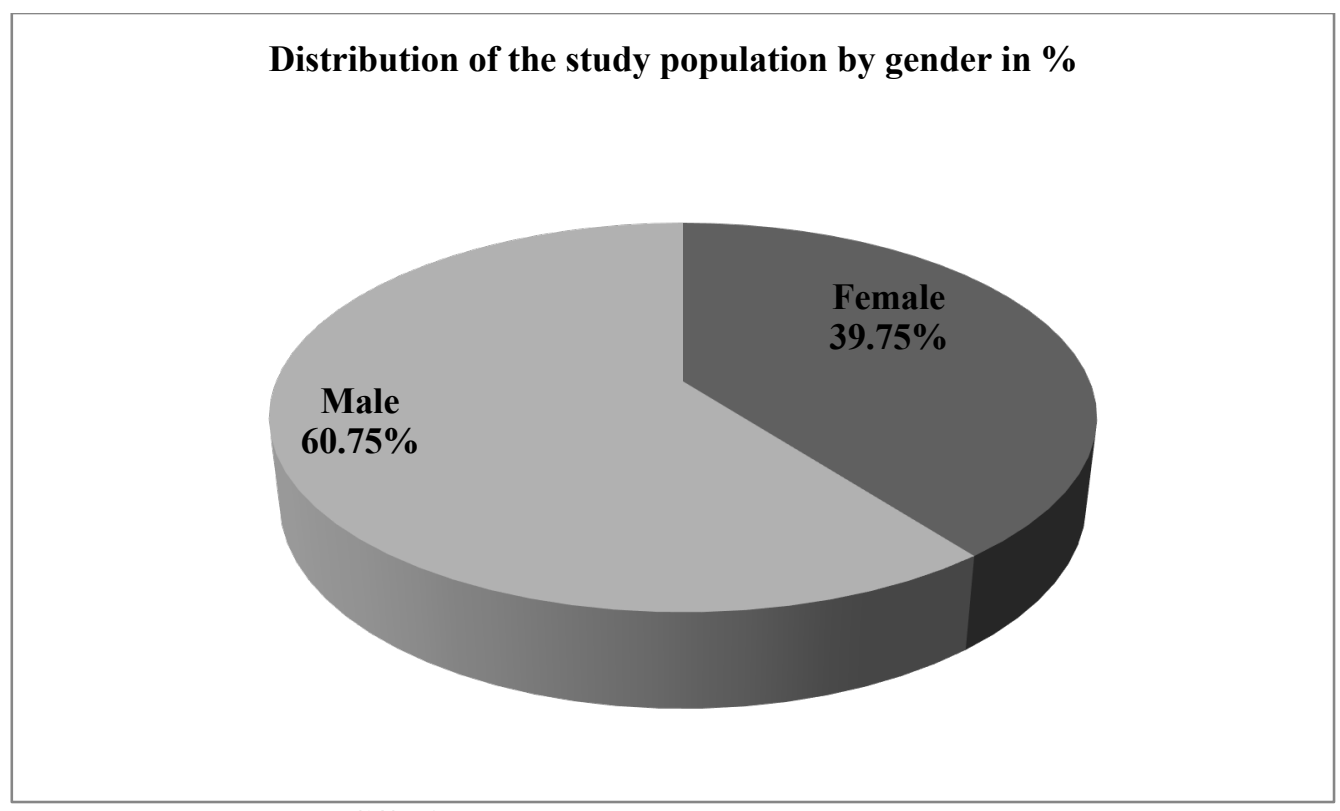

Figure 3. Percentage distribution (\%) of respondents by gender

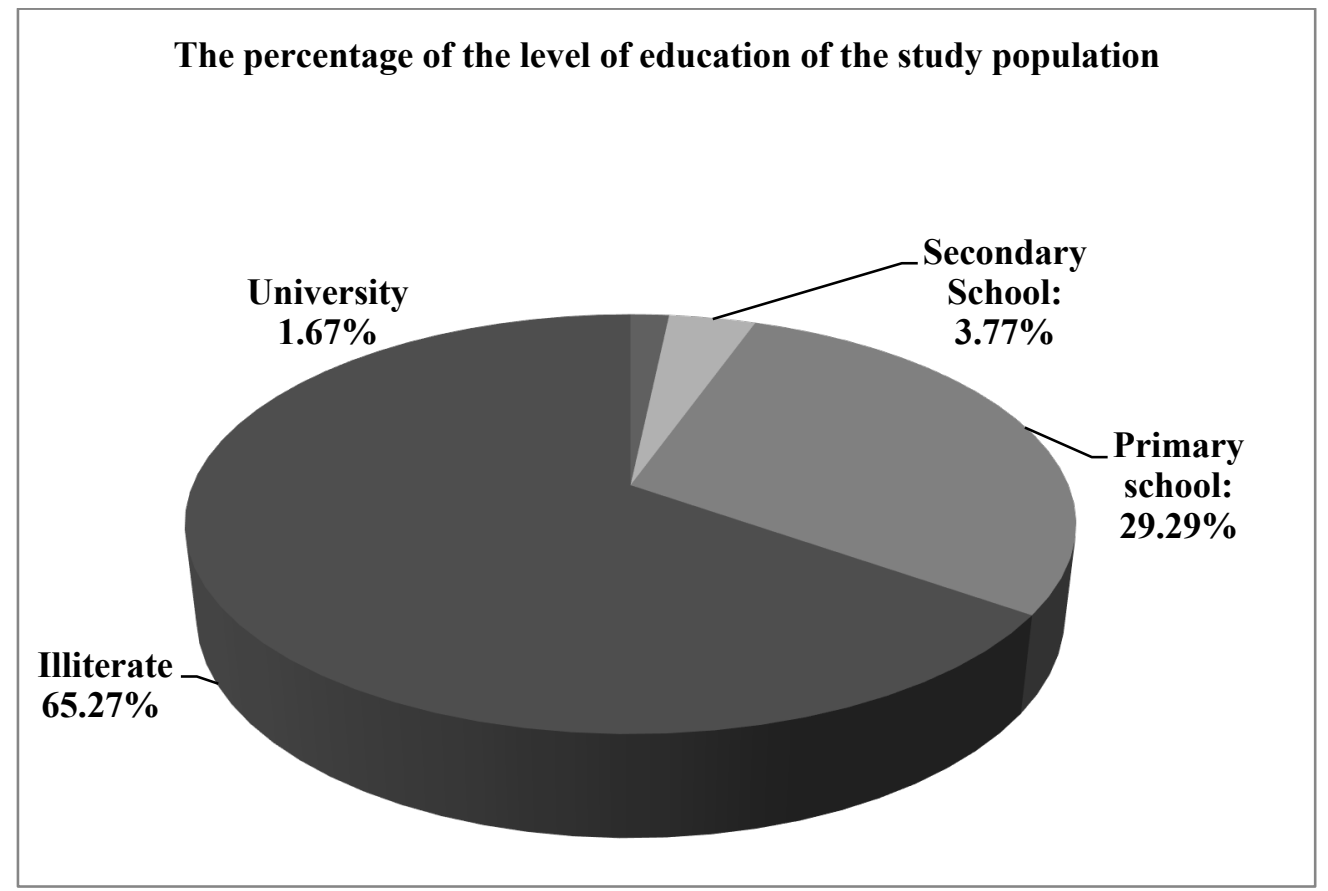

Figure 4. Distribution of respondents by level of education Socio-economic utility of the Chamaerops humilis species in the province of Taza - Morocco.

Impact of the implementation of the new Moroccan law $n^{\circ} 77-15$ published in the official Moroccan bulletin $\mathrm{N}^{\circ} 6422$ on the socio-economic position of Chamaerops humilis L. var. argentea Andre

Chamaerops humilis L. var. argentea Andre has a socio-economic interest through selling the palm heart and promoting basketry products.

To evaluate the impact of the law $n^{\circ} 77-15$ published in the Moroccan official bulletin $\mathrm{N}^{\circ} 6422$ on the evolution of the basketry market, we carried out a socio-economic survey in two phases; the first conducted from March to May, 2016, before the application of the Law $\mathrm{n}^{\circ} 77-15$, and the second phase lasted from November to March, 2017, after the application of Law $\mathrm{n}^{\circ} 77-15$ published in the Moroccan Official Gazette $N^{\circ} 6422$ on the prohibition of the manufacture, import, export, marketing and use of plastic bags (Official Bulletin 2015 Morocco).To estimate this impact, we used the difference-in-differences method; we compared the evolution of the unit selling price and the profit margin for two products: basket in Doum and the "Midouna" for they are considered as the most sold according to the survey data. The latter is used to present the 
fruit or serve bread but mainly to shell couscous and make other types of pasta.

\section{Sale of palm hearts}

Analysis of the data obtained during the first phase of the survey showed that the average number of plants collected per week is: 328 units/week/exploiter with an average profit income of $478 M A D$ / (43.22 €) / week. During the second phase of the survey, we found that the plants harvested per week decreased with an average of 203.75 units / week / exploiter by an average profit income of 370.94 MAD (33.54 €) / week although there was no change in the unit price between the two phases of the survey; it always remained between 1 and 2 MAD (0.0904- $0.18 €) /$ unit and rarely reached the $3 M A D /$ unit $(0.27 €)$ (Fig. 5 and 6 ).

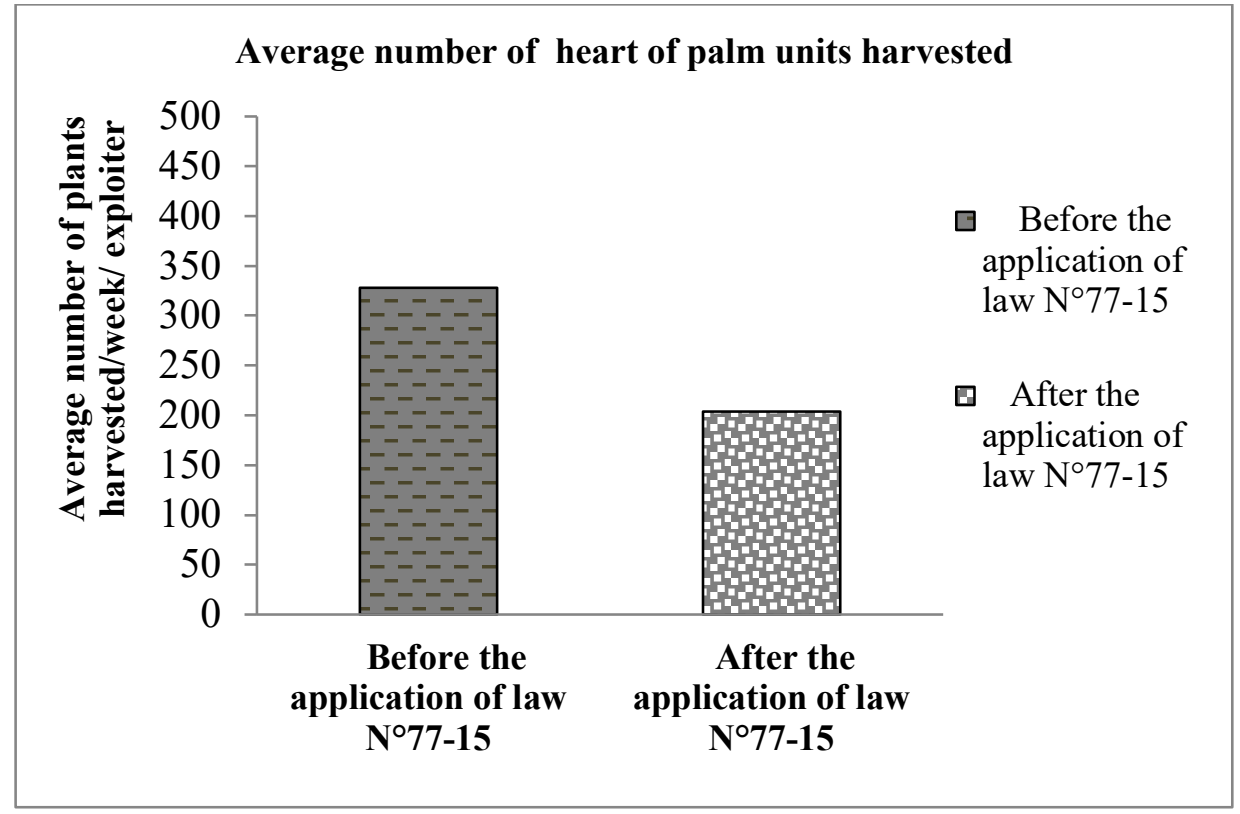

Figure 5. The variation in the average number of plants harvested/week/ exploiter before and after the application of law $n^{\circ} 77-15$ published in the Moroccan official bulletin $N^{\circ} 6422$

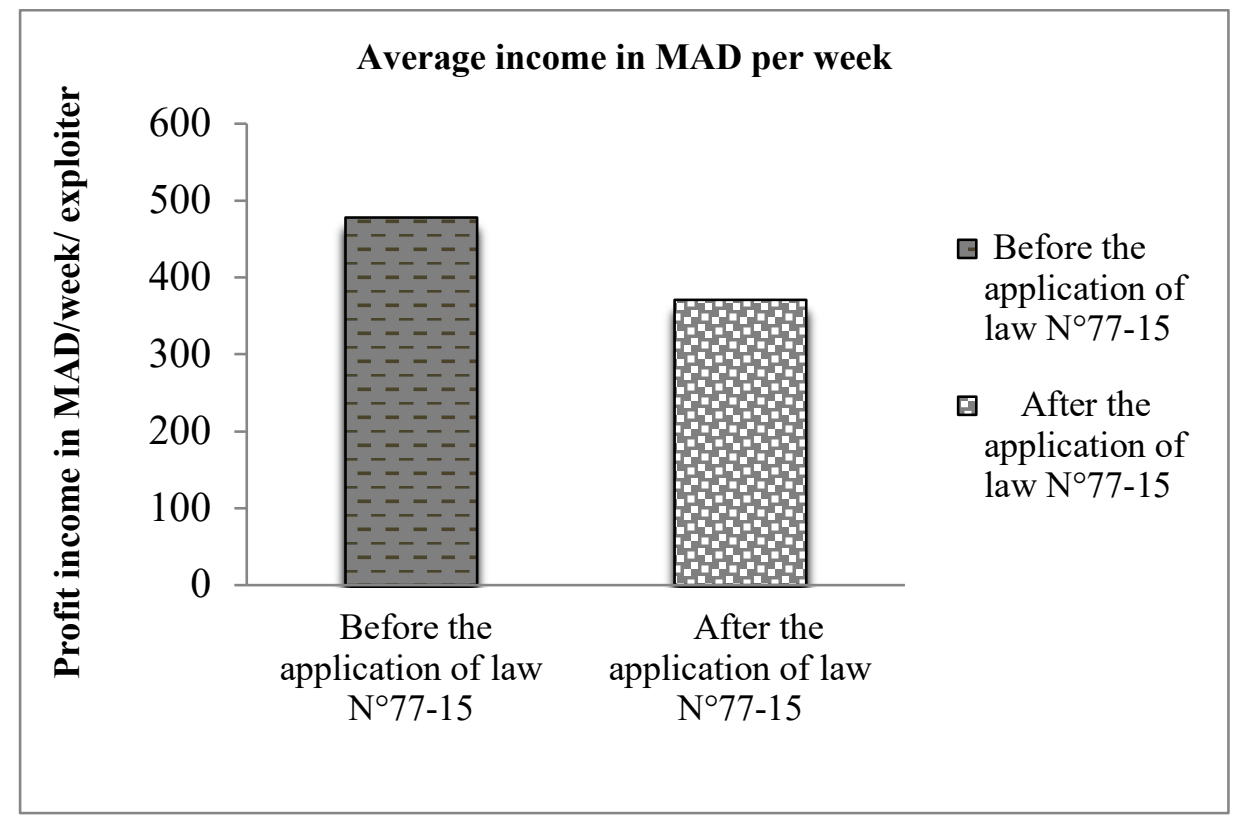

Figure 6. The variation in profit income in MAD/week/ exploiter before and after the application of the new law $n^{\circ} 77$ 15 published in the Moroccan official bulletin $N^{\circ} 6422$ 
The decrease in the number of plants harvested during the second phase of the survey could be explained, on the one hand, by the coincidence of the second phase of the survey with other agricultural activities, in particular olive harvesting, which is another source of income for the population surveyed. On the other hand, this phase does not coincide with the harvesting season of the palm kernel heart. As a result, the sale of heart of dwarf palm is a source of income but on a seasonal basis from March to June.

A study conducted of Crocus sativus L. in Morocco showed that it is a main source of income for households in mountain areas in the TaliouineTaznakht region (Aboudrare et al. 2014). Similarly, another study conducted in Nigeria found that some indigenous food plants contribute to the country's rural and national economy. For instance, Raphia spp. is an important source of palm wine that provides a source of income for thirty farmers (Okafor 1980). Another study in Ivory Coast showed that the sale of forage plants is an activity that provides job for the population, enabling them to cover their financial needs (Faustine et al. 2016). In addition, a study in the Himalayan region of Pakistan showed that forest products have a positive impact on income generation and poverty reduction in rural areas of this region (Ali \& Rahut 2018).

A study on the ecological, economic and social prospects for cocoa production worldwide revealed that crop grown has a very important economic for small farmers, it can provide the income needed to purchase food (Franzen \& Borgerhoff Mulder 2007). According to a study conducted in Mesoamerica, oil palm production provides occasional employment, moreover, oil cultivation is one of the few sources of income for the local population (CastellanosNavarretea et al. 2018). In Brazil a survey was conducted in two Caiçara communities on the Atlantic forest coast, on the Diversity of Plant Uses revealed that the fruits of some indigenous plants are important as a source of food for the population surveyed as the Clusiaceae "bacupari" and many Myrtaceae (Hanazaki et al. 2000).

According to a study conducted in Morocco, The aromatic and medicinal plants sector generates economic benefits for local rural populations, which contributes to improving the standard of living of this category, they have found 25 of priority wild aromatic and medicinal plants species with economic value for export are selected, among these species for example: Ceratonia siliqua, Thymus satureoides, Rosmarinus officinalis. (Lamrani \& Hassikou 2018).

\section{Sale of basketry products}

During our research, we found out that various Doum-based basketry products are sold in the city of Taza such as: Basket, "Tbag", "Midouna", couscous, mats, "Taraza" hats, brooms (Table 1).

According to information provided by basket makers, the price of raw material varies between 6 and 8 $M A D / \mathrm{kg}(0.54-0.72 € / \mathrm{kg})$; it sometimes reaches 10 $M A D / \mathrm{kg}(0.9 € / \mathrm{kg})$. Employees involved in the fabrication of these products are both men and women. The average age of respondents practicing in basketry is 45 years. The working time can be full or partial. The income gained from the sale of basketry product varies according to the type of product and season. It has been noted that this handcraft is the only source of income for some families in the Bni Frassen and Wlad Zbair area (57 $\mathrm{km}$, and $42 \mathrm{~km}$ from Taza) (Table 2).

During the first period of the survey before the implementation of the new law $n^{\circ} 77-15$, the average price of the raw material was $7.25 M A D / \mathrm{kg}(0.66 €$ $/ \mathrm{kg}$ ); the average number of units sold/week was 2.83 for the basket maker, and 4.66 per basket maker for the "Midouna". As for the average unit selling price, baskets reached 25.83 MAD (12.33€) while "Midouna" attained 28.33 MAD (12.56€) for each basket maker. Therefore, the profit margin for each basket weaver/ maker is 68.57 MAD (6.2 €) / week for the basket in Doum and 127.79 MAD (11.55 $€)$ for the "Midouna".

After the application of law $n^{\circ} 77-15$, the average price of the raw material has decreased slightly by $0.25 M A D(0.0226 €) / \mathrm{kg}$. The price of the raw material varies according to the season and the intensity of agricultural work. That is to say, during busy agricultural seasons, when workers are labouring their farms, the demand for raw material decreases causing decline in price. As a result, 5.5 basket units/week were sold whereas only 7 units/week of "Midouna". It seemed clear that the average number of units sold for both products has increased; it has even doubled for baskets. This increase could be explained by the impact of the awareness-raising campaigns among Moroccan citizens that accompanied the application of the new law $n^{\circ} 77-15$ on the harmful effects of plastic and the danger caused by plastic bags on the environment, which encouraged the Moroccan population to use Doum baskets as an ecological alternative, and to discover other products made of Chamaerops humilis L. var. argentea Andre such as the "Midouna". 
Table 1. The different basketry products in the province of Taza

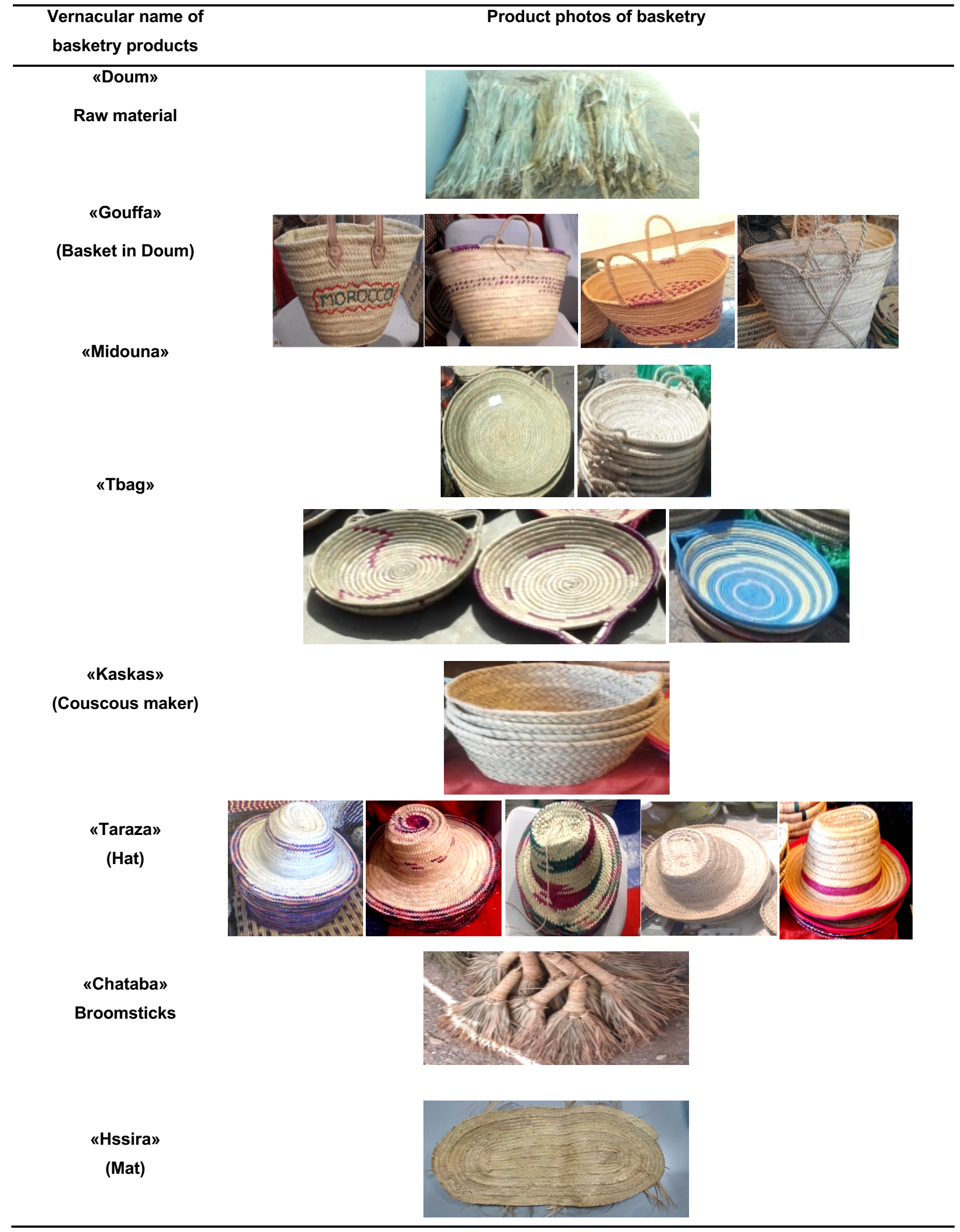


The average unit selling price of baskets increased slightly: it became 29.16 MAD (2.63€) / unit instead of 25.83 MAD (2.33€) / unit with a difference of 3.33 MAD $(0.3 €) /$ unit. Concerning the "Midouna", a slight decrease in the average unit selling price was observed, 25 MAD (2.25 €) / MAD unit instead of 28.33 MA ( $2.55 €) /$ unit. The variation of all these numbers between the two periods of the investigation affected the profit margin of both products especially Doum baskets. The latter noticeably increased by $86.56 \%(7.82 €)$ while the second product augmented by $41.96 \%$ (3.79 €) despite the slight decrease in the unit selling price thanks to the increase in the average number of units sold per week to 7 units per week from 4.66 units per week.
The increase in the profit margin for both basketry products during the second phase of the survey could be explained by the increasing need to basketry products caused by the application of the new Moroccan law $n^{\circ} 77-15$, which encouraged the use of herbal baskets. The new circumstance imposed an increase in the average number of units sold (Table 1). In Cameroon, a socio-economic survey was conducted to value and show the diversity of non-timber forest products, showed that the use of various categories of forest products is sometimes the only source of income for some local populations in Cameroon's Littoral region. For example, the income generated by the marketing of Irvingia gabonensis can reach 89000 Franc CFA (135.68 €) / month/person (Jules et al. 2011).

Table 2. Weekly profit margins for the two basketry products: Basket and "Midouna" for each basket maker

\begin{tabular}{|c|c|c|c|c|c|}
\hline Product & Description & $\begin{array}{l}\text { A.N.U.S I } \\
\text { Week }^{*}\end{array}$ & $\begin{array}{l}\text { A.U.S.P in } \\
\text { MAD* }^{*}\end{array}$ & A.C.P / Week & $\begin{array}{l}\text { A.P / Week in } \\
\text { MAD* }\end{array}$ \\
\hline \multirow[t]{2}{*}{$\begin{array}{l}\text { Basket in } \\
\text { doum }\end{array}$} & $\begin{array}{l}\text { Before the } \\
\text { application of Law } \\
n^{\circ} 77-15 \text { published in } \\
\text { the Moroccan Official } \\
\text { Bulletin } N^{\circ} 6422\end{array}$ & 2.83 & 25.83 & 4.531 & 68.57 \\
\hline & $\begin{array}{l}\text { After the application } \\
\text { of Law } n^{\circ} 77-15 \\
\text { published in the } \\
\text { Moroccan Official } \\
\text { Bulletin } N^{\circ} 6422\end{array}$ & 5.5 & 29.16 & 5.25 & 155.13 \\
\hline \multirow[t]{2}{*}{ «Midouna» } & $\begin{array}{l}\text { Before the } \\
\text { application of Law } \\
n^{\circ} 77-15 \text { published in } \\
\text { the Moroccan Official } \\
\text { Bulletin } N^{\circ} .6422\end{array}$ & 4.66 & 28.33 & 4.22 & 127.79 \\
\hline & $\begin{array}{l}\text { After the application } \\
\text { of Law } n^{\circ} 77-15 \\
\text { published in the } \\
\text { Moroccan Official } \\
\text { Bulletin } N^{\circ} 6422\end{array}$ & 7 & 25 & 5.25 & 169.75 \\
\hline
\end{tabular}

A.N.U.S / Week*: Average number of units sold per week

A.U.S.P in MAD *: Average unit selling price in MAD A.C.P / Week*: Average cost of production per week A.P / Week in MAD*: Average profit per week in MAD

For more details on the socio-economic interest of the dwarf palm in the field of artisanal basketry, we visited three cooperatives in the region of "Bni Frassen" $57 \mathrm{~km}$ away from Taza in two periods; on June 04, 2016 before the application Moroccan law $\mathrm{n}^{\circ} 77-15$ and on April 01-02, 2017 after the application of the new law. The cooperatives visited are: Mtiwa Nabat, El baraka, and Znata koufa. According to these cooperatives, basketry and agriculture are the major activities that represent a source of income for the population of "Bni Frassen".

The "Mtiwa Nabat" cooperative created in 2006, makes an important contribution to the local economy as it provides a source of income for more than 400 people. The second cooperative, "El Baraka", created in 2004 consists of thirty affiliates (26 men and 4 women), and affords a decent income for 200 people. The oldest cooperative "Znata Koufat" was created in 2000 . It also represents a source of financial income for 200 people. Beside the contract established with the Mohammed Five Foundation for Solidarity to prepare 25.000 baskets each year for the sacred month of Ramadan, "Mtiwa Nabat" delivers baskets for the distribution of food to citizens in emergencies; earthquakes, floods, especially in the north of the country where seism is intense. 
"El Baraka" is another successful cooperative whose high-quality manufacture enabled them to promote their products in the European market. In 2016, the cooperative sold the total 600 doom baskets in the international market in Germany.

After the application of the law $n^{\circ} 77-15$ published in the Moroccan official bulletin $\mathrm{N}^{\circ} 6422$, we have carried out a second visit to know the effects of the law on the market of artisanal basketry among the three cooperatives. It has been noticed that the application of the new law had a positive quantitative effect which is manifested through the increase in productivity and number of workers. On the other hand, the qualitative effects manifested through the improvement of existing products and the manufacture of new ones. Cooperatives started to develop and innovate their craft manufacturing techniques in order to produce new decorative products and accessories such as wallets, bags, storage boxes, waste baskets. This evolution is thanks to the training organized by the Moroccan Crafts Department in collaboration with the Spanish Agency for International Cooperation (SAIC) and the United Nations for Industrial Development Organization (UNIDO) and followed by craftsmen to improve their traditional skills. These training courses are aimed at the development of herbal products and also on new techniques for the manufacture of artisanal products. According to the presidents of the cooperatives, the number of workers has increased except for "El Baraka" who stated that the number of workers has remained constant and that the market evolution after the application of the new law was positive but on a periodic basis. On the other hand, "Mtiwa Nabat" is now a source of income for five thousand people according to its president. Similarly, the "Znata Koufat" cooperative aims to improve its membership in order to be more efficient and follow the two other most advanced cooperatives. The survey data reveal that all cooperatives include only those artisans who have good skills of the manufacture of basketry items. In addition, the presidents of the cooperatives visited stated that new cooperatives are being created after the application of the new law $n^{\circ} 77-15$, in order to cover the needs of baskets in the Moroccan market and to create more job opportunities for the population of the region.

Based on the findings discussed, the developing artisanal basketry sector will certainly contribute to the improvement of the local economy of the region while will maintain preservation the environment through the use of ecological alternatives to plastic bags. This is not the case in Algeria according to a study carried out by Hasnaoui and his collaborators who showed that the artisanal use of the dwarf palm exists but for too limited purposes (Hasnaoui et al. 2011).

The presidents of the cooperatives visited expressed their need to training on new techniques for the manufacture of plant-based products, on cooperative marketing, on management techniques as well as to literacy programs.

Despite the development of the basketry sector, there are still several obstacles that hinder the evolution of these cooperatives including:

- The absence of regulations that maintain the purchasing process of the raw material in the best circumstances;

- The existence of broker intermediaries who heave the competitive market of these cooperatives and influence the purchase price and added value of these cooperatives;

- The emergence of new alternatives to plastic such as new reusable bags of woven and non-woven fabric;

- Problems related to participation in fairs to exhibit basketry products like transport and accommodation expenses.

\section{Conclusions}

According to the socio-economic survey, it is clear that the implementation of the new Moroccan law $n^{\circ}$ $77-15$ published in the Moroccan Official Bulletin $\mathrm{N}^{\circ}$ 6422 has a considerable positive impact on the basketry market in the province of Taza particularly on the promotion and sale of the baskets in Doum. This evolving handcraft contributes to the development of the local economy of the region through job creation and secures a source of income for several families in the area. This consequently will benefit the development of Morocco in general. Furthermore, this activity could contribute to the preservation of the environment and human health by using ecological alternatives to plastic bags, which have harmful effects on humans and animals.

The following recommendations are suggested as research follow-up: It is highly important to raise public awareness of the importance of preserving the dwarf palm species from overexploited and contribute to the sustainable use of Chamaerops humilis L. var. argentea Andre.

\section{Declarations}

List of abbreviations: Not applicable.

Ethics approval and consent to participate: All respondents were well informed of the objectives of the study, have been well informed, the 
confidentiality of their participation and the data provided and the right to refuse to participate and withdraw at any time.

Consent for publication: Not applicable.

Availability of data and materials: The data was not deposited in public repositories.

Conflicts of interest: There is no conflict of interest. Funding sources: This work received no specific grant from any funding agency in the public, commercial, or not-for-profit sectors.

Author's contributions: NL did most of the practical work as part of a PhD thesis supervised by $\mathrm{FL}$ and $\mathrm{HT}$ and prepared the manuscript. FL designed and coordinated the study, participated in article preparation, corrected the manuscript and edited the final version and submitted it for publication. HT participated in study designed, helped to improve the manuscript and participated in the correction of the manuscript. All authors read and approved the final manuscript.

\section{Glossary}

"Zéro mica»: An operation led by the Moroccan Coalition for Climate Justice (CMJC) aims to collect and destroy plastic bags, and to raise awareness of the health and environmental harms associated with the use of plastic bags.

"Gouffa»: It is a classic handcrafted object made from dwarf palm leaves of different sizes, with two short handles covered or not with leather, It is a practical and functional tool for shopping and picnicking.

«Tbag»: Doum utensils, most often covered with wool, it is used to present dried fruit but mainly bread. «Midouna»: Flat basket, flexible with short edges and flared with one or two short handles used to prepare couscous semolina or to make other types of pasta.

"Taraza»: Hat in doum in round or oval shape, simple or colored, used to protect from the sun and heat.

«Hssira»: A classic artisanal form in the form of a carpet made from braided dwarf palm leaves, used as a furniture tool.

"Jummar»: It is the apical bud of Chamaerops humilis $L$. var. argentea Andre It is an edible part of the plant.

«Chataba»: It is a domestic object, used for cleaning soils, mats, and ovens.

\section{Acknowledgements}

Our sincerest thanks go to all respondents and especially to the basket makers and presidents of basketry cooperatives in the province of Taza who facilitated the conduct of the survey. Also, we thank Dr. Abdelouahab Zalaghi for the assistance provided in the design of the map in Figure 1 and $\mathrm{Dr}$.
Abdelmajid Khabbach for botanical identification of the plant.

\section{Literature cited}

Aboudrare A, Aw-Hassan A, Lybbert TJ. 2014. Importance socio-économique du Safran pour les ménages des zones de montagne de la région de Taliouine-Taznakht au Maroc. Revue Marocaine des Science Agronomiques et Vétérinaires 2:5-14.

Ahmad L, He Y, Hao J.-C, Semotiuk A, Liu QR, Mazari P. 2018. Toxic pyrrolizidine alkaloids provide a warning sign to overuse of the ethnomedicine Arnebia benthamii. Journal of Ethnopharmacology 210:88-94. https://doi.org/10.1016/j.jep.2017.08.009

Ali A, Rahut DB. 2018. Forest-based livelihoods, income, and poverty: Empirical evidence from the Himalayan region of rural Pakistan. Journal of Rural Studies

$57: 44-54$. doi:10.1016/j.jurstud.2017.10.001

Al-Subaiee FS. 2016. Socio-economic factors affecting the conservation of natural woodlands in Central Riyadh Area - Saudi Arabia. Saudi Journal of Biological Sciences 23:319-326. doi:10.1016/j.sjbs.2015.02.017

Aziz MA, Khan AH, Adnan M, Izatullah I. 2017. Traditional uses of medicinal plants reported by the indigenous communities and local herbal practitioners of Bajaur Agency, Federally Administrated Tribal Areas, Pakistan. Journal of Ethnopharmacology 198:268-281. doi:10.1016/j.jep.2017.01.024

Castellanos-Navarrete A, Tobar-Tomás WV, LópezMonzón CE. 2018. Development without change: Oil palm labour regimes, development narratives, and disputed moraleconomies in Mesoamerica. Journal of Rural Studies doi:10.1016/j.jrurstud.2018.08.011

Eddouks M, Ajebli M, Hebi M. 2017. Ethnopharmacological survey of medicinal plants used in Daraa-Tafilalet region (Province of Errachidia), Morocco. Journal of Ethnopharmacology 198:516-530. doi:10.1016/j.jep.2016.12.017

El Hadidi NMN, Hamdy R. 2011. Basketry Accessories: Footwear, Bags and Fans in Ancient Egypt. Journal of Archaeological Science 38:10501061. doi:10.1016/j.jas.2010.11.026

Faustine, K.A., Francis TBB, Jean KK. 2016. Etude Socio-Économique De L'exploitation Des Plantes Fourragères Dans Le District d'Abidjan (Côte d'Ivoire). European Scientific Journal, ESJ 12:357. doi:10.19044/esj.2016.v12n34p357

Fougrach H, Badri W, Malki M. 2007. Flore vasculaire rare et menacée du massif de Tazekka (région de Taza, Maroc). Bulletin de l'Institut Scientifique, Rabat, section Sciences de la Vie 29:110. 
Franzen M, Borgerhoff Mulder M. 2007. Ecological, economic and social perspectives on cocoa production worldwide. Biodiversity and Conservation 16: 3835-3849. doi:10.1007/s10531-007-9183-5

Groh KJ, Backhaus T, Carney-Almroth B, Geueke B, Inostroza PA, Lennquist A, Leslie H.A, Maffini M, Slunge D, Trasande L, Warhurst AM, Muncke J. 2019. Overview of known plastic packagingassociated chemicals and their hazards. Science of The Total Environment 651:3253-3268. doi:10.1016/j.scitotenv.2018.10.015

Hanazaki N, Tamashiro JY, Leitão-Filho HF, Begossi A. 2000. Diversity of plant uses in two Caiçara communities from the Atlantic Forest coast, Brazil. Biodiversity and Conservation 9:597-615. doi:10.1023/A:1008920301824

Hasnaoui O, Bouazza M, Benali O. 2011. Impact socio-économique du Chamaerops humilis L. var. argentea Andre dans la société Algérienne. Annales de I'Université de Bechar ISSN 1112-6604.

Haut-commissariat au Plan, 2004. Recensement général de la population et de l'habitat de 2004, 68.

Heinrich M, Lardos A, Leonti M, Weckerle C, Willcox M, Applequist W, Ladio A, Lin Long C, Mukherjee P, Stafford G. 2018. Best practice in research: Consensus Statement on Ethnopharmacological Field Studies - ConSEFS. Jopurnal of Ethnopharmacology 211:329-339. doi:10.1016/j.jep.2017.08.015.

Jules PR, Flore NJ, Jacques E, Ndongo D, Akoa A. 2011. Les produits forestiers non ligneux d'origine végétale: valeur et importance dans quelques marchés de la région du Littoral-Cameroun. Journal of Applied Bioscience 40:2715-2726.

Khabbach A, Libiad M, Ennabili A, Bousta D. 2012. Medicinal and cosmetic use of plants from the province of Taza, Northern Morocco. Boletín Latino americano y del Caribe de Plantas Medicinales y Aromáticas 1:46 - 60.

Kull CA, Harimanana SL, Radaniela Andrianoro A, Rajoelison LG. 2019. Divergent perceptions of the 'neo-Australian' forests of lowland eastern Madagascar: Invasions, transitions, and livelihoods. Journal of Environmental Management 229:48-56. doi:10.1016/j.jenvman.2018.06.004

Kuniyal CP, Rawat YS, Oinam SS, Kuniyal JC, Vishvakarma SCR. 2005. Kuth (Saussurea lappa) cultivation in the cold desert environment of the Lahaul valley, northwestern Himalaya, India: arising threats and need to revive socio-economic values. Biodiversity and Conservation 14:1035-1045. doi:10.1007/s10531-004-4365-x

Lamrani A., Hassikou R. 2018. Rapid risk assessment to harvesting of wild medicinal and aromatic plant species in Morocco for conservation and sustainable management purposes. Biodiversity and Conservation

$27: 2729-2745$. doi:10.1007/s10531-018-1565-3

Li E, Deng Q, Zhou Y. 2019. Livelihood resilience and the generative mechanism of rural households out of poverty: An empirical analysis from Lankao County, Henan Province, China. Journal of Rural Studies. doi:10.1016/j.jrurstud.2019.01.005

Libiad M, Khabbach A, Ennabili A. 2011. Exploitation of plants from upstream of the Sebou-wadi watershed (province of Taounate, North of Morocco). Bio Diversity Conservation 4:81-91

Liu F, Liu G, Zhu Z, Wang S, Zhao F. 2019. Interactions between microplastics and phthalate esters as affected by microplastics characteristics and solution chemistry. Chemosphere 214:688-694. doi:10.1016/j.chemosphere.2018.09.174

Martino S, Muenzel D. 2018. The economic value of high nature value farming and the importance of the Common Agricultural Policy in sustaining income: The case study of the Natura 2000 Zarandul de Est (Romania). Journal of Rural Studies 60: 176-187. doi:10.1016/j.jrurstud.2018.04.002

Martins A.O, Shackleton CM. 2018. The production and commercialization of palm wine from Hyphaenecoriacea and Phoenix reclinata in Zitundo area, southern Mozambique. South African Journal of Botany 116:6-15. doi:10.1016/j.sajb.2018.02.389

Mehdioui R, Kahouadji A. 2007. Etude ethnobotanique auprès de la population riveraine de la forte d'Amsittène: cas de la Commune d'Imin'Tlit (Province d'Essaouira). Bulletin de l'Institut Scientifique, Rabat, section Sciences de la Vie 29:11-20.

Merlo M E, Aleman M, Cabello J, Penas J. 1993. On the Mediterranean Fan Palm Chamaerops humilis, in: On the Mediterranean Fan Palm Chamaerops humilis, Revista Principes de l'international Palm Society 37:151-158.

Okafor J.1980. Edible Indigenous woody plants in the rural economy of the Nigerian forest zone. Forest Ecology and Management 3:45-55. doi:10.1016/0378-1127(80)90004-3

Paniagua-Zambrana NY, Byg A, Svenning JC, Moraes M, Grandez C, Balslev H. 2007. Diversity of palm uses in the western Amazon. Biodiversity and Conservation 16:2771-2787. doi:10.1007/s10531007-9218-y

Prescott TAK, Homot P, Lundy FT, Fang R, Patrick S, Cámara-Leret R, Kiapranis R. 2017. Tropical ulcer plant treatments used by Papua New Guinea's Apsokok nomads. Journal of Ethnopharmacology 205:240-245.

https://doi.org/10.1016/j.jep.2017.05.001

Quézel P, Barbero M, Benabid A, Rivas-martínez S. 1992. Contribution à l'étude des groupements 
forestiers et pré-forestiers du Maroc Oriental. Stvdia Botánica 10:57-90.

Richard P. 2005. Classification et reconnaissance des plantes. Revue Francaise de Allergologie et Immunologie Clinique 45:189-193. doi:10.1016/j.allerg.2005.02.006.

Rochefort H. 2013. Bisphénol A et cancers hormonodépendants: Risque potentiel et mécanisme d'action. Rev médecine/sciences 29, 539-544. doi:10.1051/medsci/2013295019

Sadat-Hosseini M, Farajpour M, Boroomand N, Solaimani-Sardou F. 2017. Ethnopharmacological studies of indigenous medicinal plants in the south of Kerman, Iran. Journal of Ethnopharmacology 199:194-204. doi:10.1016/j.jep.2017.02.006

Sher H, Al Yemeni M. 2011. Economically and ecologically important plant communities in high altitude coniferous forest of Malam Jabba, Swat, Pakistan. Saudi Journal of Biological Sciences 185361. doi:10.1016/j.sjbs.2010.09.002

Tagemouati NL, Berroho Y, Abou El Aazm A, Fili A. 2010. Diagnostic régional de l'économie du patrimoine culturel: Enquêtes et recherches de terrain pour spécifier les données du diagnostic de l'économie du patrimoine culturel dans les régions de Guelmim-Smara, Souss-Massa-Draa, Taza-Al Houceima-Taounate et l'Oriental. (Report of the Agency of Architecture Héritageet Design (AAHD) P: 7 http://www.mdgfund.org/sites/default/files/CULT_ET UDE_Morroco_Diangnostic\%20regional\%20de $\% 20$ I economie\%20du\%20patrimonine\%20culturel.pdf

Talukdar S, Adhikari PP, Borah A. 2017. Ethnomedicobotanical study of indigenous knowledge on medicinal plants used for the treatment of reproductive problems in Nalbari district, Assam, India. Journal of Ethnopharmacology 210:386-407. doi:10.1016/j.jep.2017.07.024

Valdes B. 2013. Checklist of the vascular plants collected during the fifth "Iter Mediterraneum" in Morocco, 8-27 June, 1992. Bocconea 26: 13-132. http://dx.doi.org/10.7320/bocc26.013

Weckerle CS, de Boer HJ, Puri RK, van Andel T, Bussmann RW, Leonti M. 2018. Recommended standards for conducting and reporting ethnopharmacological field studies. Journal of Ethnopharmacology 210:125-132. doi:10.1016/j.jep.2017.08.018 